\title{
Study of Utilization of Waste Water in Concrete
}

\author{
Mr. Asif Rashid Shaikh ${ }^{1}$,Dr. V. M. Inamdar ${ }^{2}$ \\ 1(M.E. IInd Year, Department of Civil Engineering, G.H. Raisoni College of Engineering and Management, \\ Savitribai Phule Pune University) \\ 2(Former Professor, Department of Civil Engineering, G.H. Raisoni College of Engineering and \\ Management,Savitribai Phule Pune University \& Presently Professor, Department of Applied \\ Mechanics, Walchand College of Engineering,Sangli,Maharashtra,India )
}

\begin{abstract}
The Efficient water use is one of the most important requirement of cleaner production and the use of wastewater in concrete production important means to this end. However there are no studies of quality of concrete plant wastewater. and the activities in which water can be used. This paper aim to evaluate the quality of concrete plant wastewater and to propose guidelines for its treatment for non potable application. The type of water used for the mixing did not affect the concrete slump and density. However setting time were found to increase with water quality deteriorating. Because of scarcity of potable water it is very important to use this treated waste water in concrete in our industry.
\end{abstract}

Keywords: Ground Granulated Blast Furnace Slag (GGBS), Compressive Strength.

\section{Introduction}

In India the population is rapidly developing simultaneously the construction industry is also developing. In construction industry there is no substitute of concrete. it is very important part of structure. concrete need a potable water but now a days specially in summer season the scarcity of water is a major global problem at that time we need to study other types of water that is a waste water and it is collected from the river. now a days we are loosing million liters of waste water and there is no provision to use this water rather than farming. after testing waste water in a lab if it is give similar result than the potable water then we need to use this waste water for construction purpose.

In waste water there is a lots of bacteria there is possibility of killing this bacteria in heat of hydration so we can easily used concrete for residential purpose. the benefit of this project is we save millions litter of waste water which we dispose in the river

\subsection{Wastewater Treatment in Kuwait}

\section{Related Work}

The wastewater collection and treatment system in Kuwait has been well established since the seventies. This system which collects the municipal wastewater from all part of Kuwait city. The waste water is pumped through this intricate network by 17 major pumping station and 52 secondary pumping station scattered throughout the city and its shrubs. The collected wastewater is then transferred to three wastewater treatment plant surrounding Kuwait city.

The three plant are:

1)Ardhiya WWTP

2)Jahra WWTP

3)Reqqa WWTP

\subsubsection{Use of treated waste water in concrete in Kuwait}

The "conventional Wisdom" in the concrete technology literature has been that water use for mixing and curing concrete would be satisfactory if it is potable and fit for human consumption. The reason for this is that municipal drinking water seldom contain more than $1000 \mathrm{mg} / \mathrm{l}$ of dissolved solids. Seawater, which contain about $35000 \mathrm{mg} / \mathrm{l}$ dissolved salts or more, has not been found harmful to the strength of plain concrete. However, with reinforced and prestressed concrete, the risk of corrosion is increased; therefore, the use of sea water as mixing water should be avoided under these circumstances although researchers performed on the use of raw and treated wastewater in concrete mixing and curing spares.

\subsubsection{Concrete Mix Design}

The concrete mix was design according to Neaville to achieve a compressive strength of $25 \mathrm{Mpa}$. The maximum size was $20 \mathrm{~mm}$, water content $=200 \mathrm{~kg} / \mathrm{cum}$, water cement ratio of 0.62 and slump is $75 \mathrm{~mm}$. 


\subsection{The Effect Of Waste Wash Water On Concrete Properties}

Malaysia is one of the developing countries. During this era of globalization, there are a lot of extreme construction works all over the world. Nowadays, the environmental pollution in Malaysia is increased same as the development of our country.

It has been calculated that about 9-m3 ready-mixed concrete truck contains, at the end of each working day, approximately $200-400 \mathrm{~kg}$ of returned plastic concrete. this material can be left overnight in the truck with the addition of hydration control admixtures or washed out. When washed out, with the addition of about 700 $1300 \mathrm{~L}$ of water, the material can be mechanically separated into aggregates ready for reuse and water containing amounts of suspended fine particles. Consequently, partial and complete recycle of waste wash water are usually adopted in the manufacturing plants. By the former method, water is collected in sedimentation basins: hence, clarified water is reused in the production, while sediment must be disposed of in authorized landfills; on the contrary, full recycle represents an environmentally safe and cheap procedure, because wash water is totally reused as mixing water in the production and no disposal procedure is involved.

\subsubsection{Waste wash water in ready-mix concrete plant}

Recycling waste water in the production of new concrete, but gives some restrictions for its composition and use. In this paper, the use of waste wash water (coming from a medium-size ready-mixed concrete plant) in mixing water for concrete and mortars has been investigated: the effects on physicalmechanical properties and microstructure are investigated as a function of the characteristics of waste water used. The results have shown that mortar and concrete prepared with recycled water exhibit 28-day mechanical strength in no way lower than $96 \%$ of the reference materials (90\% is the minimum allowed in prEN 1008) and, in some cases, even better. Moreover, the use of wash water in concrete leads to a reduction of the concrete capillary water absorption and mortar micro porosity, which surely improves the durability of the material.

\section{Methodology}

1. To determine the mix design for M20 grade of concrete.

2. To determine physical properties of treated water.

3. Cast a no. of cubes for following combination:

- Use of $100 \%$ cement content in mix design.

- Use of Cement $(80 \%)+$ Fly ash $(20 \%)+$ treated waste water in the mix design.

- Use of Cement $(80 \%)+$ GGBS $(20 \%)+$ treated waste water in the mix design.

4. Testing of Concrete cubes on 7th,14th,28th day.

\section{Experimental Work}

Mix No.1: Use of $100 \%$ cement content in mix design:

Material:

A. Cement - Ordinary Portland cement of 53 grade confirming to IS:12269-1987 used in the investigation

B. Fine aggregate - Crush sand confirming to Zone-II used as fine aggregate.

C. Coarse Aggregate - Locally available crushed angular coarse aggregates of size $20 \mathrm{~mm}$ and $10 \mathrm{~mm}$ with specific gravity of 2.7 was used as Coarse aggregate

D. GGBS - Confirming to IS 12089:1981

E. HVFA - High Volume Fly Ash as per the laboratory test conducted according to ASTM method C1202

F. Water - Locally available potable water confirming to IS 456-2000 is used

\begin{tabular}{|l|l|l|}
\hline Materials & For 1 cum in $\mathrm{kg}$ & For 6 cubes in $\mathrm{kg}$ \\
\hline W/C & 0.5 & $\ldots$ \\
\hline Cement & 300 & 7.5 \\
\hline Fly Ash & $\ldots$ & $\ldots$ \\
\hline GGBS & $\ldots$ & $\ldots$ \\
\hline 20mm Aggregate & 619 & 15.47 \\
\hline 10mm Aggregate & 446 & 11.15 \\
\hline Crush Sand & 912 & 22.8 \\
\hline Water & 175 & 4.375 \\
\hline Admixture(1\%) & 3.15 & 0.078 \\
\hline
\end{tabular}

Mix No.2: Use of Cement $(80 \%)+$ Fly ash(20\%) in the mix design:

\begin{tabular}{|l|l|l|}
\hline Materials & For 1 cum in $\mathrm{kg}$ & For 6 cubes in $\mathrm{kg}$ \\
\hline W/C & 0.5 & $\ldots$ \\
\hline Cement & 240 & 7.5 \\
\hline Fly Ash & 60 & 6.0 \\
\hline GGBS & $\ldots$ & $\ldots$ \\
\hline
\end{tabular}




\begin{tabular}{|l|l|l|}
\hline 20mm Aggregate & 619 & 15.47 \\
\hline 10mm Aggregate & 446 & 11.15 \\
\hline Crush Sand & 912 & 22.8 \\
\hline Water & 175 & 4.375 \\
\hline Admixture(1\%) & 3.15 & 0.078 \\
\hline
\end{tabular}

Mix No.3: Use of Cement( $80 \%)+\operatorname{GGBS}(20 \%)$ in the mix design:

\begin{tabular}{|l|l|l|}
\hline Materials & For 1 cum in $\mathrm{kg}$ & For 6 cubes in $\mathrm{kg}$ \\
\hline W/C & 0.5 & $\ldots$ \\
\hline Cement & 240 & 7.5 \\
\hline Fly Ash & $\ldots$ & $\ldots$ \\
\hline GGBS & 60 & 6.0 \\
\hline 20mm Aggregate & 619 & 15.47 \\
\hline 10mm Aggregate & 446 & 11.15 \\
\hline Crush Sand & 912 & 22.8 \\
\hline Water & 175 & 4.375 \\
\hline Admixture(1\%) & 3.15 & 0.078 \\
\hline
\end{tabular}

Results:

Result: For $100 \%$ cement content in mix design.

\begin{tabular}{|l|l|l|}
\hline Day of Test & Compressive Strength in Mpa & Avg.Compressive strength in Mpa \\
\hline $7^{\text {th }}$ day & 16.67 & \\
\hline $7^{\text {th }}$ day & 17.77 & 16.66 \\
\hline $7^{\text {th }}$ day & 15.55 & \\
\hline $14^{\text {th }}$ day & 21.33 & \\
\hline $14^{\text {th }}$ day & 19.11 & 20.88 \\
\hline $14^{\text {th }}$ day & 22.22 & \\
\hline $28^{\text {th }}$ day & 23.56 & \\
\hline $28^{\text {th }}$ day & 26.67 & 25.11 \\
\hline $28^{\text {th }}$ day & 25.11 & \\
\hline
\end{tabular}

: Use of Cement $(80 \%)+\operatorname{GGBS}(20 \%)$ in the mix design

\begin{tabular}{|l|l|l|}
\hline Day of Test & Compressive Strength in Mpa & Avg.Compressive strength in Mpa \\
\hline $7^{\text {th }}$ day & 22.66 & \\
\hline $7^{\text {th }}$ day & 20.1 & 21.03 \\
\hline $7^{\text {th }}$ day & 20.15 & \\
\hline $14^{\text {th }}$ day & 21.33 & \\
\hline $14^{\text {th }}$ day & 20.11 & 20.86 \\
\hline $14^{\text {th }}$ day & 21.15 & \\
\hline $28^{\text {th }}$ day & 36.88 & \\
\hline $28^{\text {th }}$ day & 37.77 & 37.17 \\
\hline $28^{\text {th }}$ day & 36.88 & \\
\hline
\end{tabular}

Use of Cement $(80 \%)+$ Fly ash(20\%) in the mix design

\begin{tabular}{|l|l|l|}
\hline Day of Test & Compressive Strength in Mpa & Avg.Compressive strength in Mpa \\
\hline $7^{\text {th }}$ day & 21.87 & \\
\hline $7^{\text {th }}$ day & 21.55 & 21.40 \\
\hline $7^{\text {th }}$ day & 20.80 & \\
\hline $14^{\text {th }}$ day & 22.33 & \\
\hline $14^{\text {th }}$ day & 21.11 & 21.53 \\
\hline $14^{\text {th }}$ day & 21.15 & \\
\hline 28 th day & 20.00 & \\
\hline 28 th day & 23.11 & 21.62 \\
\hline 28 th day & 21.77 & \\
\hline
\end{tabular}

\section{Conclusion}

With the comparison of potable water concrete and treated waste water concrete are gives nearly similar results. Now a days there is so much scarcity of water. Therefore there is need to arrange other source of water for concrete or construction of building units. This treated waste water which now a days drains in river can use in concrete.

\section{Acknowledgement}

I have great pleasure to express my deep sense of gratitude and sincere regards to my guide Dr. V. M. Inamdar, for his guidance and friendly discussion which helped me immensely in selecting this topic. His generous encouragement throughout my dissertation work helped me in completing this project work. I would like to thank our Head of Civil Engineering Department Prof. N.C. Dubey for allowing me to do this project. He 
has immensely helped in providing all opportunities and facilities for the project work. I am thankful to all the faculty members of Civil Engineering and library staff for helping me in this work. Finally, I would like to thank all those who directly or indirectly helped me during my work.

\section{References}

[1]. Brix, H.; Schierup, H.-H. The use of macrophytes in water pollution control. AMBIO 1989, 18, 100-107.

[2]. Vymazal, J.; Kröpfelová, L. Wastewater Treatment in Constructed Wetlands with Horizontal Sub-Surface Flow; Springer: Dordrecht, The Netherlands, 2008.

[3]. G. Siracusa, A.D. La Rosa. ( $\left.\begin{array}{llll}2 & 0 & 0 & 6\end{array}\right)$ Design of a constructed wetland for wastewater treatment in a Sicilian town and environmental evaluation using the emergy analysis 490-497.

[4]. Chazarenc F., Gagnona V., Comeau Y. and Brisson J. (2009). "Effect of plant and artificial aeration on solids accumulation and biological activities in constructed wetlands". Ecological Engineering (35), 1005-1010.

[5]. G. Siracusa, A.D. La Rosa (2 006 ) Design of a constructed wetland for wastewater treatment in a Sicilian town and environmental evaluation using the emergy analysis 490-497

[6]. Sonavane P. (2008). "Mechanism and kinetics of nitrogen and phosphorous removal in root zone treatment of domestic waste". $\mathrm{Ph} . \mathrm{D}$ thesis submitted to Shivaji University, Kolhapur.

[7]. Wallace S., Higgins J., Crolla A., Kinsley C., Bachand A. and Verkuijl S. (2006) "High-rate AMMONIA removal in Aerated Engineered Wetland". $10^{\text {th }}$ International Conference on Wetland Systems for Water Pollution Control (Lisbon, Portugal), 23-29.

[8]. Plamondon C., Chazarenc F., Comeau Y. and Brisson J. (2006). "Artificial aeration to increase pollutant removal efficiency of constructed wetlands in cold climate". Ecological Engineering (27), 258-264. 